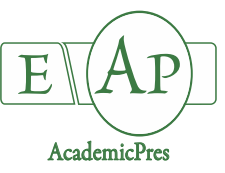

Curovic M et al. (2020)

Notulae Botanicae Horti Agrobotanici Cluj-Napoca 48(3):1699-1708

DOI: $10.15835 /$ nbha48311992

Research Article

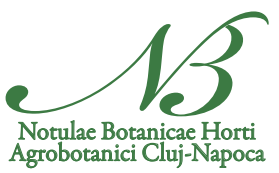

\title{
Structural characteristics of the mixed spruce - fir - beech forests on Mountain Bjelasica in Montenegro
}

\section{Milic CUROVIC ${ }^{1}$, Aleksandar STIJOVIC ${ }^{2}$, Velibor SPALEVIC ${ }^{3 *}$, Branislav DUDIC ${ }^{4,5}$, Milos PAJIC $^{6}$}

\author{
${ }^{1}$ University of Montenegro, Biotechnical Faculty, Mihaila Lalica 1,81000 Podgorica, Montenegro; curovic@ucg.ac.me \\ ${ }^{2}$ Institute of Forestry, Novaka Miloseva 1,81000 Podgorica, Montenegro; stijovicaleksandar@gmail.com \\ ${ }^{3}$ University of Montenegro, Faculty of Philosophy, Department of Geography, 81400 Niksic, Montenegro; \\ velibor:spalevic@gmail.com ("corresponding author) \\ ${ }^{4}$ Comenius University in Bratislava, Faculty of Management, 82005 Bratislava, Slovakia; \\ branislav.dudic@fm.uniba.sk \\ ${ }^{5}$ University Business Academy, Faculty of Economics and Engineering Management, 21000 Novi Sad, Serbia; \\ branislav.dudic@fimek.edu.rs \\ ${ }^{6}$ University of Belgrade, Faculty of Agriculture, Nemanjina 6, Belgrade - Zemun, Serbia; paja@agrif.bg.ac.rs
}

\begin{abstract}
Biogradska Gora National Park in Montenegro is part of the Bjelasica Mountain which belongs to the montane region of the Dinaric Alps. Biogradska Gora is one of the largest long-term preserved forests in the Southeast Europe. In this paper there were compared the main structural characteristics of the old-growth mixed forest of spruce (Picea abies L.), fir (Abies alba L.) and beech (Fagus moesiaca (Domin, Maly) Czecz.), from the preserved area of the Biogradska Gora, with similar managed forests from the same mountain. Basic insight into the structural characteristics of forests of spruce, fir and beech was obtained by analyzing tree species composition and two basic structural elements - number of trees and wood volume per unit area. The obtained data provides overview of the structural characteristics of these forests. The results revealed the production potential of the studied mixed forests. The average quantity of standing volume in old-growth forests of Biogradska Gora indicates very valuable and productive forest ecosystems. Presented data shows that forest ecosystems of spruce, fir and beech in the protected area of the National Park Biogradska Gora are characterized by structurally irregular forests with presence of old trees with relevant growing stock and optimal balance of beech and conifer species, while in managed forests on the same mountain, growing stock is very low and with structure which is far from optimal.
\end{abstract}

Keywords: Biogradska Gora; Bjelasica; mixed forest; Montenegro; old-growth forest

\section{Introduction}

Mixed mountain forests of beech (Fagus moesiaca (Domin, Maly) Czecz.), fir (Abies alba L.) and spruce (Picea abies L.) represent one of the major forest types in Eastern and Southeast Europe (Horvat et al., 1974; O'Hara et al., 2018). The three-dominant forests of beech, fir and spruce (Piceeto-Abieti-Fagetum s. lat.) in 
Montenegro are forests of high site class in which all three species reach high dimensions in terms of height and thickness, especially in old-growth stands.

Norway spruce, silver fir, and European beech are three of the most widely distributed and economically important tree species in Europe (Torresan et al., 2020). Mixed mountain forests of beech, spruce, and fir at elevations between 600 and $1400 \mathrm{~m}$ above sea level cover an area of more than 10 million hectares in Europe (Brus et al., 2012). The forests of fir, spruce and beech (Piceo-Abieti-Fagetum Čol. 1965.) according to the First National Forests Inventory of Montenegro (MARD, 2013), occupy 4.7\% of the total area covered by forest in Montenegro.

European mixed mountain forests have been stable in terms of volume growth in relation to climate change (Hilmers et al., 2019). Three species mixture of beech, spruce, and fir in optimal climate and site conditions shown higher productivity than neighbouring pure stands (Pretzsch et al., 2015) and ecologically are more resilient than single-species forests (Griess et al., 2012; Lebourgeois et al., 2013; Pretzsch et al., 2013). This could be very important for adaptability and for mitigating climate change impacts. Knowledge of structural elements and species composition of old-growth forests should be base for management approaches according to the future climate changes (Millar et al., 2007). Structural characteristics of old-growth forests are important starting points for defining the goals in forests that are managed on a regular basis (Vasic et al., 2018) and represent a worthy model for management and structuring of managed forests. Natural selection in primary forests may provide solutions for forest management that could lead to stands with higher stability and superior wood quality (Chivulescu et al., 2019). The significance of this research according to Bosela et al. (2015) is also resembled in the fact that there is modest knowledge about competitive and facilitative interactions between trees and species in the mixed spruce-fir-beech forests. Studies of old-growth forests structure and comparison with similar managed forests are becoming increasingly important for the improvement of silviculture and for understanding environmental changes (Diaci et al., 2011). Many studies in recent years increasingly support the idea of nature-based silviculture (Lafond et al., 2015; Nolet et al., 2017).

Intensive forest exploitation in Europe caused their compositional and structural homogenization and simplification, leaving only remnants of old-growth temperate forest ecosystems (Axelsson and Oestlund, 2001) which is main reason why comparison studies between old-growth forests and similar managed forests in Europe are rare. The Biogradska Gora mixed Abies-Picea-Fagus forest on the Mountain Bjelasica in Montenegro is one of the largest remaining old-growth forests in the Southeast Europe (Motta et al., 2015).

The main goal of this paper is to provide an overview of the structural characteristics of the mixed forests of beech, fir and spruce in Biogradska Gora National Park as a realistic basis for close-to-nature management of similar stands. Because of the rarity and fragmentation of old-growth forests, comparative research of those and managed forests is especially important for understanding forest ecosystem functioning and for the development of close-to-nature forest management strategies. Those studies are needed to improve knowledge on how anthropogenic factors are influencing compositional and structural changes of the forests. In this paper we compared the main structural characteristics of the mixed forest from the preserved area of the Biogradska Gora with similar managed forests from the same Mountain Bjelasica (Figure 1).

\section{Materials and Methods}

For the forest measurement of Management Unit (MU) Bjelasica has been used a conventional forest inventory sampling procedure regular with $100 \mathrm{~m}$ grid of sample plots. Each grid intersection defined the centre of a circular sampling plot (radius $=17.84 \mathrm{~m}$, area $=1000 \mathrm{~m}^{2}$ ). In each plot, all live trees with the diameter at breast height $(\mathrm{DBH})>10 \mathrm{~cm}$ were tallied and sorted by species (MARD 2013). 

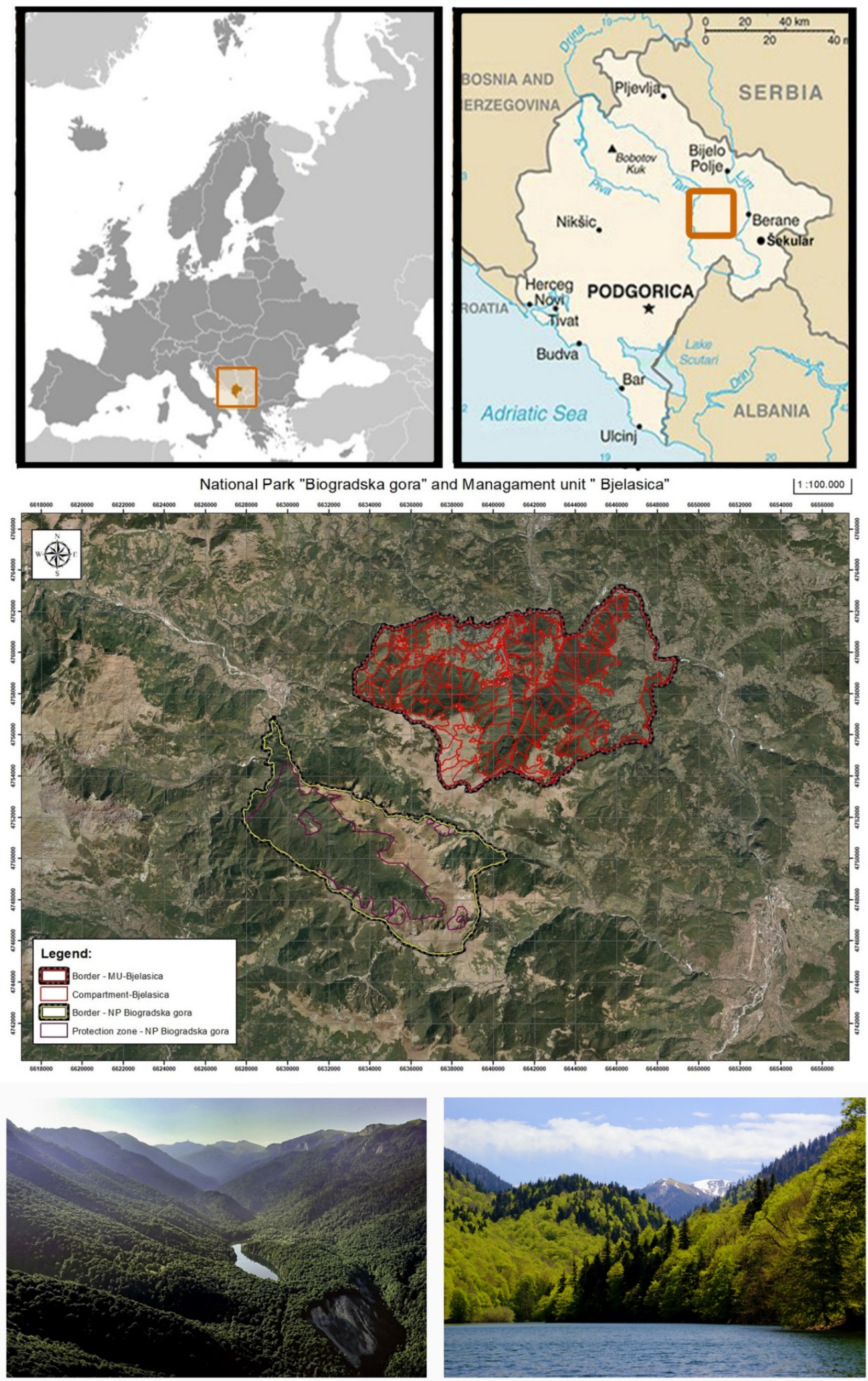

Figure 1. Position and panoramic view of National Park Biogradska Gora and Management Unit (MU) Bjelasica 
The field research in Biogradska Gora included collection of data in four sample plots in the strict protection zone. Selection of the areas for sample plots was focused on forest stands at the optimal stage phase according the Korpel theory (Korpel, 1995). The sample plots of 0.25 ha were clearly marked in the field, with coordinates recorded using a GPS device. Diameter at breast height and the heights $(\mathrm{h})$ of the trees were measured for all live trees with a minimum DBH threshold of $10 \mathrm{~cm}$. The diameter at breast height in the research plots was measured using tree callipers to the nearest $1 \mathrm{~mm}$ at $1.3 \mathrm{~m}$ height.

Volume was calculated for each individual tree by the method of direct equalization of volumes, according to Schumacher-Hall's function:

$$
\mathrm{V}=\mathrm{ad}^{\mathrm{b}} \mathrm{h}^{\mathrm{c}}
$$

Where ' $\mathrm{d}$ ' is diameter at breast height, and ' $h$ ' is high of the tree.

Value of coefficients 'a', 'b' and 'c' for all three species in Montenegro was calculated using Montenegrin volume tables (Markovic, 2004).

The final calculations were obtained by using software "Osnova v 6.4.2.".

\section{Results}

The Structure of mixed forests of beech, spruce and fir of the Mountain Bjelasica in Montenegro were examined by accessing data of three basic stand parameters: (1) stand diameter and volume structure (2) number of trees per ha and (3) tree species composition. The forest structure data were aggregated separately for old-growth forests of National Park Biogradska Gora and for managed forests of Management Unit (MU) "Bjelasica".

\section{MU Bjelasica}

Mixed fir, spruce and beech forests in better habitats (Management class 103) make up 34.3\% of the total area of commercial forests of the MU Bjelasica (Stijovic, 2017). These stands are found in quite heterogeneous habitats, on soils whose depth ranges from to medium deep to deep. The total area of these forests in the management unit is 804.4 ha.

The number of trees per unit area is 811 trees per hectare. The total wood volume is $229159 \mathrm{~m}^{3}$ or 284.8 $\mathrm{m}^{3} / \mathrm{ha}$. The volume structure by diameter classes and tree species is shown in Table 1 . The total current annual volume increment in these forests is $6.7 \mathrm{~m}^{3} / \mathrm{ha}$. The average intensity of increments is $2.4 \%$.

Table 1. Timber volume structure of MU Bjelasica

\begin{tabular}{|c|c|c|c|c|c|c|c|c|c|c|c|}
\hline \multirow{3}{*}{ Species } & \multicolumn{11}{|c|}{$\begin{array}{l}\text { Management unit (MU) Bjelasica } \\
\text { Volume per diameter classes }\end{array}$} \\
\hline & \multirow{2}{*}{$\begin{array}{l}\text { Sum } \\
\left(\mathrm{m}^{3}\right)\end{array}$} & \multirow{2}{*}{$\begin{array}{c}\text { Sum } \\
(\%)\end{array}$} & $\begin{array}{c}10-20 \\
\mathrm{~cm}\end{array}$ & $\begin{array}{c}21-30 \\
\mathrm{~cm}\end{array}$ & $\begin{array}{c}31-40 \\
\mathrm{~cm}\end{array}$ & $\begin{array}{c}41-50 \\
\mathrm{~cm}\end{array}$ & $\begin{array}{c}51-60 \\
\mathrm{~cm}\end{array}$ & $\begin{array}{c}61-70 \\
\mathrm{~cm}\end{array}$ & $\begin{array}{c}71-80 \\
\mathrm{~cm}\end{array}$ & $\begin{array}{c}81-90 \\
\mathrm{~cm}\end{array}$ & $\begin{array}{l}\text { above } \\
90 \mathrm{~cm}\end{array}$ \\
\hline & & & I & II & III & IV & $\mathrm{V}$ & VI & VII & VIII & IX \\
\hline Beech & 163.4 & 57.3 & 23.4 & 29.9 & 31.8 & 31.0 & 20.1 & 12.5 & 7.7 & 3.6 & 3.4 \\
\hline Fir & 50 & 17.5 & 13.1 & 15.7 & 9.9 & 5.7 & 1.6 & 1.6 & 0.8 & 0.7 & 0.9 \\
\hline Spruce & 32.6 & 11.4 & 5.1 & 9.3 & 7.9 & 5.2 & 2.1 & 1.2 & 0.7 & 0.4 & 0.7 \\
\hline Other species & 39.2 & 13.8 & 12.5 & 14.0 & 5.5 & 2.4 & 1.6 & 1.1 & 0.6 & 0.5 & 1.0 \\
\hline Total & 285.2 & 100.0 & 54.1 & 68.9 & 55.1 & 44.3 & 25.4 & 16.4 & 9.8 & 5.2 & 6.0 \\
\hline
\end{tabular}

Stands in the MU Bjelasica, except for rather low values of the standing timber volume, are characterized by a low proportion of the volume of the timber in the diameter classes above $50 \mathrm{~cm} \mathrm{DBH} \mathrm{(Table} \mathrm{3).} \mathrm{There} \mathrm{is}$ also a large participation of accompanying species. The share of the main tree species in the mixture is $86.2 \%$. The share of fir and spruce in the mixture of $28.9 \%$ is very far from the optimal state $(80 \%)$, while on the other hand there is an excess of beech (57.3\%) and other accompanying species (Populus tremula L., Betula pendula 
Roth., Acer pseudoplatanus L., Fraxinus excelsior L. and other species) of as much as $13.8 \%$, which will require a longer period of time to achieve the optimal scale ratio of the mixture.

\section{Biogradska Gora}

The achieved tree dimensions and timber volume in old-growth forests can serve as an indicator of the productivity of these stands (Curovic et al., 2020). Although a smaller number of trees occurred per unit of area (on average, 349 trees/ha), the presence of remnant trees of large dimensions resulted in substantially high growing stock of $795,6 \mathrm{~m}^{3} / \mathrm{ha}$.

Table 2. Timber volume structure of Biogradska Gora

\begin{tabular}{|c|c|c|c|c|c|c|c|c|c|c|c|}
\hline \multirow{3}{*}{ Species } & \multicolumn{11}{|c|}{$\begin{array}{c}\text { Biogradska Gora } \\
\text { Volume per diameter classes }\end{array}$} \\
\hline & \multirow{2}{*}{$\begin{array}{l}\text { Sum } \\
\left(\mathrm{m}^{3}\right)\end{array}$} & \multirow{2}{*}{$\begin{array}{l}\text { Sum } \\
(\%)\end{array}$} & $\begin{array}{c}10-20 \\
\mathrm{~cm}\end{array}$ & $\begin{array}{c}21-30 \\
\mathrm{~cm}\end{array}$ & $\begin{array}{c}31-40 \\
\mathrm{~cm}\end{array}$ & $\begin{array}{c}41-50 \\
\mathrm{~cm}\end{array}$ & $\begin{array}{c}51-60 \\
\mathrm{~cm}\end{array}$ & $\begin{array}{c}61-70 \\
\mathrm{~cm}\end{array}$ & $\begin{array}{c}71-80 \\
\mathrm{~cm}\end{array}$ & $\begin{array}{c}81-90 \\
\mathrm{~cm}\end{array}$ & $\begin{array}{l}\text { above } \\
90 \mathrm{~cm}\end{array}$ \\
\hline & & & I & II & III & IV & V & VI & VII & VIII & IX \\
\hline Beech & 169.7 & 21.3 & 5.2 & 14.1 & 25.8 & 33.2 & 23.9 & 27.8 & 23.1 & 16.6 & 0.0 \\
\hline Fir & 361.0 & 45.4 & 4.5 & 16.4 & 27.9 & 25.5 & 40.1 & 62.0 & 61.2 & 55.9 & 67.5 \\
\hline Spruce & 264.9 & 33.3 & 0.9 & 3.3 & 5.0 & 18.9 & 30.0 & 24.5 & 27.5 & 6.7 & 148.1 \\
\hline Total & 795.6 & 100 & 10.6 & 33.8 & 58.7 & 77.6 & 94.0 & 114.3 & 111.8 & 79.2 & 215.6 \\
\hline
\end{tabular}

The share of coniferous species is quite favourable and amounts to $78.7 \%$. This is especially pronounced in diameter classes above $50 \mathrm{~cm}$. The accompanying species in these stands have no share in the wood volume.

The difference in the volume distribution by wider diameter classes (Table 3) between the stands of MU Bjelasica and Biogradska Gora best shows the structural difference of the studied stands.

Table 3. The structure of growing stock by wider diameter classes

\begin{tabular}{|l|c|c|}
\hline \multicolumn{1}{|c|}{ Diameter classes } & $\begin{array}{c}\text { MU Bjelasica } \\
(\%)\end{array}$ & $\begin{array}{c}\text { Biogradska Gora } \\
(\%)\end{array}$ \\
\hline $\mathrm{DBH}<30 \mathrm{~cm}$ & 43.1 & 5.6 \\
\hline $\mathrm{DBH} 31-50 \mathrm{~cm}$ & 34.9 & 17.1 \\
\hline $\mathrm{DBH}>50 \mathrm{~cm}$ & 22.0 & 77.3 \\
\hline
\end{tabular}

The average timber volume found in the sample plots in Biogradska Gora was more than twice greater than the volume in the managed forests in the same Mountain of Bjelasica. The distribution by diameter classes shows that the stands of MU Bjelasica have a structure close to selective forests, while the stands on Biogradska Gora have structure characteristic for old-growth forest communities, with a small number of trees in the lowest diameter classes.

\section{Discussion}

An optimal growing stock for mixed forests of spruce, fir and beech between 320 and $430 \mathrm{~m}^{3} / \mathrm{ha}$, depending on habitat conditions in Montenegro, has been accepted as an axiom in forestry science and practice. The optimal growing stock for those forests in better habitats is $410 \mathrm{~m}^{3} /$ ha, with optimal mixture of $80 \%$ of conifers (fir 50 and spruce 30) and 20\% of beech (Medarevic, 2006; Curovic et al., 2013).

In the best managed spruce-fir-beech stands on the Mountain Ljubišnja in Montenegro average tree volume of $404.3 \mathrm{~m}^{3} / \mathrm{ha}$ at the Vukodol site and $584.4 \mathrm{~m}^{3} / \mathrm{ha}$ at the Sula site were recorded (Curovic et al., 
2011). According to presented structure, growing stock and tree species composition, forest stands from MU Bjelasica completely deviates from the optimal ones. The reason should certainly be sought in the management practice, due to the intensity of cutting in the past period and due to the uneven treatment of felling of beech and coniferous species. The above data indicate that the existing wood volume in these forests is lower by 125 $\mathrm{m}^{3} /$ ha than optimal. The share of conifers in the mixture is below 30\%. A high percentage of accompanying species is also evident as a consequence of greater disturbance of the canopy and inadequate felling.

On the other hand, the average quantity of standing volume of $795.6 \mathrm{~m}^{3} /$ ha in forests of Biogradska Gora indicates quite different situation. Growing stock is almost twice the average. The ratio of beech and coniferous species is very close to optimal. According the results of the studies on mixed beech, fir and spruce forests in Serbia in the best sites of the national park Tara the average growing stock is $462.84 \mathrm{~m}^{3} / \mathrm{ha}$ (Medarević et al., 2007) and Mountain Zlatar $510 \mathrm{~m}^{3} / \mathrm{ha}$ (Matović, 2005). Govedar et al. (2006), studying the old-growth forests Lom in the Bosnia and Herzegovina, recorded a volume from 600 to $1343 \mathrm{~m}^{3} / \mathrm{ha}$.

The achieved tree dimensions and timber volume in old-growth forests can serve as an indicator of the productivity of these stands. Presence of large-diameter trees is an attribute of the old-growth forests (Bahus et al., 2009; Keren et al., 2017). The high percentage of volume in diameter classes above $50 \mathrm{~cm}$ dbh in Biogradska Gora shows the old-growth forest character of these stands. The right asymmetry of the volume structure is particularly pronounced in spruce. Norway spruce is important for the productivity but in dense stands, regeneration growth of spruce could be suppressed (Stancioiu and O'Hara, 2006).

Despite the high degree of forest naturalness, the share of fir in European blending forests is decreasing (Jaworski et al., 2002; Diaci et al., 2010; Bottero et al., 2011; Vacek et al., 2014). Primeval forest structure and full canopy is especially suited for fir. In the studied stands on Biogradska Gora, the share of fir is quite good, while it is not case in managed forests of MU Bjelasica. Natural regeneration of fir in the full canopy parts of the mixed forests is much higher than in the open parts (Klopčić et al., 2010). Completely fencing virgin forests is currently the only way of ensuring relatively natural spontaneous development of mixed spruce-fir beech forests (Vrska et al., 2006).

Models and silvicultural guidelines may consider our findings by regulating the species and size distributions in order to reach higher values of growing stock. As a general principle, silvicultural interventions should foster J-shaped size distributions in European spruce-fir-beech mountain forest stands (Torresan et al., 2020).

In our study, noticeable differences between managed selection forests and corresponding virgin forests were detected in diameter structure, stand volume and the presence of large-diameter trees. Similar differences in the analysed stand parameters were found in other studies (Goodburn and Lorimer, 1999; Štefančik et al., 2006; Janowiak et al., 2008; Diaci et al., 2010). The single-tree selection system is similar to a natural gap disturbance regime in old-growth forests (Angers et al., 2005). Forest management practice of selective forests in Montenegro used more often group selection than individual tree selection (Bončina et al., 2014). The results presented in this paper show that this principle of management has not given good results in practice.

\section{Conclusions}

The analysis of structural parameters of three-dominant spruce, fir and beech forests (Piceo-AbietiFagetum) on Bjelasica Mountain in Montenegro showed significant differences in the condition of managed forests in relation to protected old-growth forests. In the managed forests of the MU "Bjelasica" in addition to the smaller growing stock, tree species composition seen through share of beech and coniferous species has also been significantly disturbed. In the forests of the Biogradska Gora National Park, the species ratio is close to optimal, while the growing stock is almost three times higher in relation to the managed forests of the same Mountain. This shows that the current situation in managed forests is far from the potential of habitats. A 
significant share of accompanying species is also noticeable in managed forests and it will take a long time for these stands to reach the optimal condition.

The presented comparison showed the advantage of the close-to-nature management and individual tree selection. These results are in line with presented recent trends in forestry. The presented structural elements of intact forests in this case preserved area of the Biogradska Gora National Park, can serve as a good guide in creating management goals for similar forests.

\section{Authors' Contributions}

Conceptualization: MC and VS; Work on the field: MC, AS and VS; Methodology: MC and AS.; Software: MC, AS and VS.; Calculations: MC, MP, BD and AS; Formal analysis, MC and MP; Literature: MC and MP; Data curation, MC, MP; W riting - original draft preparation, MC; Writing - review and editing: MC, MP and VS; Visualization: AS, VS and MP; Supervision, VS; Project administration: BD; Funding acquisition, BD.

All authors read and approved the final text of the manuscript. All authors read and approved the final text of the manuscript.

\section{Acknowledgements}

This research received no specific grant from any funding agency in the public, commercial, or not-forprofit sectors.

The hereby work was accepted and presented at the GEA (Geo Eco-Eco Agro) International Conference 28 May 2020, Podgorica, Montenegro, and it has been published as abstract in "Book of Abstracts" (http://www.gea.ucg.ac.me/page.php?id=64).

\section{Conflict of Interests}

The authors declare that there are no conflicts of interest related to this article.

\section{References}

Angers VA, Messier C, Beaudet M, Leduc A (2005). Comparing composition and structure in old-growth and harvested (selection and diameter-limit cuts) northern hardwood stands in Quebec. Forest Ecology and Management 217:275-293. http://dx.doi.org/10.1016/j.foreco.2005.06.008

Axelsson AL, Ostlund L (2001). Retrospective gap analysis in a Swedish boreal forest landscape using historical data. Forest Ecology and Management 147:109-122. https://doi.org/10.1016/S0378-1127(00)00470-9

Bauhus J, Puettmann K, Messier C (2009). Silviculture for old-growth attributes. Forest Ecology and Management 258:525-537. http://dx.doi.org/10.1016/j.foreco.2009.01.053

Boncina A, Cavlovic J, Curovic M, Govedar Z, Klopcic M, Medarević M (2014). A comparative analysis of recent changes in Dinaric uneven-aged forests of the NW Balkans. Forestry 87(1):71-84. https://doi.org/10.1093/forestry/cpt038

Bosela M, Tobin B, Seben V, Petras R, Larocque GR (2015). Different mixtures of Norway spruce, silver fir, and European beech modify competitive interactions in central European mature mixed forests. Canadian Journal of Forest Research 45 (11):1577-1586. https://doi.org/10.1139/cjfr-2015-0219

Bottero A, Garbarino M, Dukic V, Govedar Z, Lingua E, Nagel TA, Motta R (2011). Gap-phase dynamics in the oldgrowth forest of Lom, Bosnia and Herzegovina. Silva Fennica 45(5):875-887. 
Brus DJ, Hengeveld GM, Walvoort DJJ, Goedhart PW, Heidema AH, Nabuurs GJ, Gunia K (2012). Statistical mapping of tree species over Europe. European Journal of Forest Research 131:145-157. https://doi.org/10.1007/s10342011-0513-5

Chivulescu S, Leca S, Ciceu A, Pitar D, Apostol B (2019). Predictors of wood quality of trees in primary forests in the Southern Carpathians. Agriculture and Forestry http://www.agricultforest.ac.me/paper.php?journal_id=213\&id=2902

Curovic M, Spalevic V, Sestras P, Motta R, Dan C, Garbarino M, Vitali A, Urbinati C (2020). Structural and ecological characteristics of mixed broadleaved old-growth forest (Biogradska Gora - Montenegro). Turkish Journal of Agriculture and Forestry 44: 428-438. https://journals.tubitak.gov.tr/agriculture/abstract.htm?id=27602

Curovic M, Spalevic V, Medarevic M (2013). The ratio between the real and theoretically normal number of trees in the mixed forests of fir, beech and spruce in the national park "Biogradska gora". Agriculture \& Forestry 59(1):7-17.

Curovic M, Medarevic M, Pantic D, Spalevic V (2011). Mayor Types of mixed forests of spruce, fir and beech in Montenegro. Austrian Journal of Forest Science 128(2):93-111.

Diaci J, Rozenbergar D, Anic I, Mikac S, Saniga M, Kucbel S, Visnjic C, Ballian D (2011). Structural dynamics and synchronous silver fir decline in mixed old-growth mountain forests in Eastern and Southeastern Europe. Forestry 84(5):479-491. https://doi.org/10.1093/forestry/cpr030

Diaci J, Rozenbergar D, Boncina A (2010). Stand dynamics of Dinaric old-growth forest in Slovenia: Are indirect human influences relevant? Plant Biosystems 144:194-201.

Goodburn JM and Lorimer CG (1999). Population structure in old-growth and managed northern hardwoods: an examination of the balanced diameter distribution concept. Forest Ecology and Management 118:11-29. https://doi.org/10.1016/S0378-1127(98)00478-2

Govedar Z, Stanivuković Z, Čuković D, Lazendić Z (2006). Basic taxation characteristics of mixed stands of beech, fir and spruce in "Lom" rainforest in the area of western part of the Republika Srpska; Proceedings of Scientific Conference: "Management of forest eco systems of the national parks and other protected areas" pp 285-295.

Griess VC, Acevedo R, Härtl F, Staupendahl K and Knoke T (2012). Does mixing tree species enhance stand resistance against natural hazards? A case study for spruce. Forest Ecology and Management 267:284-296. https://doi.org/10.1016/j.foreco.2011.11.035

Hilmers T, Avdagić A, Bartkowicz L, Bielak K, Binder F, Bončina A, ... Pretzsch H (2019). The productivity of mixed mountain forests comprised of Fagus sylvatica, Picea abies, and Abies alba across Europe. Forestry 92(5):512-522. https://doi.org/10.1093/forestry/cpz035

Horvat I, Glavac V, Ellenberg H (1974). Vegetation Sudosteuropas. Geobotanica selecta 4. - G. Fischer-Verlag, Stuttgart 1974, 768 S, 412 Abb, 153 Tab, 2 farbige Karten.

Janowiak MK, Nagel LM, Webster CR (2008). Spatial scale and stand structure in northern hardwood forests: implications for quantifying diameter distributions. Forest Science 54(5):497-506. https://doi.org/10.1093/forestscience/54.5.497

Jaworski A, Kolodziej ZB, Porada K (2002). Structure and dynamics of stands of primeval character in selected areas of the Bieszczady National Park. Journal of Forest Science 48:185-201.

Keren S, Diaci J, Motta R, Govedar Z (2017). Stand structural complexity of mixed old-growth and adjacent selection forests in the Dinaric Mountains of Bosnia and Herzegovina. Forest Ecology and Management 400:531-541. https://doi.org/10.1016/j.foreco.2017.06.009

Klopcic M, Jerina K, Boncina A (2010). Long-term changes of structure and tree species composition in Dinaric unevenaged forests: Are red deer an important factor? European Journal of Forest Research 129:277-288. https://link.springer.com/article/10.1007/s10342-009-0325-Z

Korpel S (1995). Die Urwalder der Westkarpaten. Fischer, Stuttgart.

Lafond V, Cordonnier T, Courbaud B (2015). reconciling biodiversity conservation and timber production in mixed uneven-aged mountain forests: Identification of ecological intensification pathways. Environmental Management 56(5):1118-1133. https://link.springer.com/article/10.1007/s00267-015-0557-2

Lebourgeois F, Gomez N, Pinto P, Mérian P (2013). Mixed stands reduce Abies alba tree-ring sensitivity to summer drought in the Vosges mountains, western Europe. Forest Ecology and Management 303:61-71. https://doi.org/10.1016/j.foreco.2013.04.003

MARD (2013). Ministry of Agriculture and Rural Development, Montenegro. The first national forest inventory of Montenegro. Final report. Podgorica, Montenegro p 347.

Marković D (2004). Šumarske tablice. Institut za šumarstvo, Podgorica 1-172. 
Matović B (2005). Normalno stanje u smrčevo jelovim šumama - ciljevi i problemi gazdovanja na Zlataru. Magistarski rad, Šumarski fakultet, Beograd.

Medarevic M, Bankovic S, Pantic D, Petrovic N (2007). Structural and production characteristics of forest types of Tara. In: Proceedings Basic ecological and structural production characteristics of forest types of Đerdap and Tara pp 179-210.

Medarević M (2006). Forest Management Planning: University in Belgrade. Forestry Faculty pp 1-40.

Millar CI, Stephenson NL, Stephens SL (2007). Climate change and forests of the future: Managing in the face of uncertainty. Ecological Applications 17:2145-2151.

Motta R, Garbarino M, Berretti R, Bjelanovic I, Borgogno Mondino E, Čurović M, Keren S, Meloni F, Nosenzo A (2015). Structure, spatio-temporal dynamics and disturbance regime of the mixed beech - silver fir - Norway spruce oldgrowth forest of Biogradska Gora (Montenegro). Plant Biosystems 149(6):966-975. https://doi.org/10.1080/11263504.2014.945978

Nolet P, Kneeshaw D, Messier C, Béland M (2017). Comparing the effects of even- and uneven-aged silviculture on ecological diversity and processes: A review. Ecology and Evolution 8(2):1217-1226. https://doi.org/10.1002/ece3.3737

O’Hara KL, Bončina A, Diaci J, Anić I, Boydak M, Curovic M, ... Velkovski N (2018). Culture and silviculture: Origins and evolution of silviculture in Southeast Europe. International Forestry Review 20(1):130-143. https://doi.org/10.1505/146554818822824228

Pretzsch H, Biber P, Uhl E, Dauber E (2015). Long-term stand dynamics of managed spruce-fir-beech mountain forests in Central Europe: structure, productivity and regeneration success. Forestry 88:407-428. https://doi.org/10.1093/forestry/cpv013

Pretzsch H, Schütze G, Uhl E (2013). Resistance of European tree species to drought stress in mixed versus pure forests: evidence of stress release by inter-specific facilitation. Plant Biology 15:483-495. https://doi.org/10.1111/j.14388677.2012.00670.x

Stancioiu PT, O’Hara KL (2006). Regeneration growth in different light environments of mixed species, multiaged, mountainous forests of Romania. European Journal of Forest Research 125:151-162. https://doi.org/10.1007/s10342-005-0069-3

Štefančik I (2006). Changes in tree species composition, stand structure, qualitative and quantitative production of mixed spruce, fir and beech stand on Stara Pila research plot. Journal of Forest Science 52(2):74-91.

Stijovic A (2017). Program gazdovanja šumama GJ “Bjelasica”. Institut za šumarstvo, Podgorica pp 1-313.

Torresan C, del Río M, Hilmers T, Notarangelo M, Bielak K, Binder F, ... Pretzsch H (2020). Importance of tree species size dominance and heterogeneity on the productivity of spruce-fir-beech mountain forest stands in Europe. Forest Ecology and Management 457:117716. https://doi.org/10.1016/j.foreco.2019.117716

Vacek Z, Vacek S, Lukas B, Kral J, Remes J, Bulusek D, Kralicek I (2014). Ungulate impact on natural regeneration in spruce-beech-fir stands in Černy dul Nature Reserve in the Orlicke Hory Mountains, case study from Central Sudetes. Forests 5:2929-2946. https://doi.org/10.3390/f5112929

Vasic V, Pantic D, Medarevic M, Obradovic S, Cukovic D (2018). Old-growth beech forests in Serbia. Fresenius Environmental Bulletin 27(3):1498-1507.

Vrška T, Hort L, Odehnalova P, Adam D, Horal D (2001). Boubin virgin forest after 24 years (1972-1996)-Development of tree layer. Journal of Forest Science 47:439-456. 
OPEN ACCESS

(c) (1)

The journal offers free, immediate, and unrestricted access to peer-reviewed research and scholarly work. Users are allowed to read, download, copy, distribute, print, search, or link to the full texts of the articles, or use them for any other lawful purpose, without asking prior permission from the publisher or the author.

License - Articles published in Notulae Botanicae Horti Agrobotanici Cluj-Napoca are Open-Access, distributed under the terms and conditions of the Creative Commons Attribution (CC BY 4.0) License. (C) Articles by the authors; UASVM, Cluj-Napoca, Romania. The journal allows the author(s) to hold the copyright/to retain publishing rights without restriction. 